\title{
Germination and vigor of stored Jatropha (Jatropha curcars L.) seeds ${ }^{1}$
}

\author{
Solange Carvalho Barrios Roveri Jose ${ }^{2 *}$, Antonieta Nassif Salomão ${ }^{2}$, \\ Luis Alberto Martins Palhares de $\mathrm{Melo}^{2}$, Izulmé Rita Imaculada Santos², \\ Bruno Galvêas Laviola ${ }^{3}$
}

\begin{abstract}
Jatropha seeds are classified as orthodox. However, since it is an oil seed species, adequate storage conditions are required to ensure their longevity. The objective of this work was to evaluate the physiological quality of jatropha seeds stored in different environments and packaging, for periods of 3, 9 and 15 months. Three types of seed packaging bags (high density plastic bag, aluminized envelope and multiwall paper bag) were used, and the storage environments were cold and dry chamber $\left(20{ }^{\circ} \mathrm{C}\right.$ and $15 \% \mathrm{RH}$, constant), refrigerator $\left(7 \pm 3{ }^{\circ} \mathrm{C}, 48 \pm 8 \% \mathrm{RH}\right)$ and laboratory conditions $\left(25 \pm 3{ }^{\circ} \mathrm{C}, 51 \pm 7 \%\right.$ $\mathrm{RH})$. The initial moisture content and seed germination were $7.1 \%$ and $89 \%$, respectively. During storage, the physiological quality (germination and vigor) and moisture content of the seeds were evaluated. Seed water content ranged from 3.3 to $7.7 \%$, depending on the permeability of the packaging and the storage environment. The highest longevity (15 months) without loss of viability was observed for jatropha seeds with initial moisture of $7.1 \%$, packed in semipermeable plastic. Seed vigor was maintained, regardless of the environment and the type of packaging used, for up to nine months of storage.
\end{abstract}

Index terms: Jatropha curcas L., conservation, packaging, physiological quality.

\section{Germinação e vigor de sementes de pinhão manso (Jatropha curcas L.) armazenadas}

\begin{abstract}
RESUMO - As sementes de pinhão manso são classificadas como ortodoxas, mas por ser uma espécie oleaginosa é preciso que as condições de armazenamento sejam adequadas, para garantir a sua longevidade. O objetivo nesse trabalho foi avaliar a qualidade fisiológica das sementes de pinhão manso armazenadas em diferentes ambientes e embalagens, por períodos de três, nove e 15 meses. As embalagens utilizadas para o acondicionamento das sementes foram saco plástico de alta densidade, envelope aluminizado e saco de papel multifoliado e os ambientes para o armazenamento foram câmara fria e seca $\left(20{ }^{\circ} \mathrm{C}\right.$ e $15 \%$ de UR, constantes), geladeira $\left(7 \pm 3{ }^{\circ} \mathrm{C} ; 48 \pm 8 \%\right.$ de UR) e laboratório $\left(25 \pm 3{ }^{\circ} \mathrm{C} ; 51 \pm 7 \%\right.$ de UR). A umidade e a germinação iniciais das sementes eram de $7,1 \%$ e $89 \%$, respectivamente. Durante o armazenamento foram realizadas avaliações da qualidade fisiológica (germinação e vigor) e da umidade das sementes. O conteúdo de água das sementes variou de 3,3 a 7,7\%, dependendo da permeabilidade da embalagem e das condições ambientais de armazenamento. Em período de armazenamento de nove meses houve manutenção do vigor das sementes, independentemente do ambiente e do tipo de embalagem utilizada. Sementes de pinhão manso com umidade inicial de 7,1\% podem ser armazenadas por 15 meses, sem perda de viabilidade, desde que acondicionadas em embalagem plástica semipermeável.
\end{abstract}

Termos para indexação: Jatropha curcas L., conservação, embalagens, qualidade fisiológica.

\section{Introduction}

With the advent of renewable fuels, many oleaginous plants have been investigated with the objective of providing raw material for the production of biodiesel, and jatropha

${ }^{1}$ Submitted on 08/01/2017. Accepted for publication on 11/10/2017.

${ }^{2}$ Embrapa Recursos Genéticos e Biotecnologia, Caixa Postal 023725, 70770-917 - Brasília, DF, Brasil.
(Jatropha curcas L.) is one of them. In addition to the agronomic characteristics of interest, like the high grain yield, management compatible with the profile of family agriculture (Laviola et al., 2011), adaptability to different climatic regions, and the nondirect competition with food production (Freitas et al., 2011),

${ }^{3}$ Embrapa Agroenergia, Caixa Postal 40315, 70770-901 - Brasília, DF, Brasil. *Corresponding author <solange.jose@embrapa.br> 
jatropha seeds present high yields in oil,which havethe proper quality to produce biofuel (Abdelgadir et al., 2008).

Despite the interest in alternative sources for the production of fuels, jatropha cultivation still depends on researches to be feasible, and to guaranteethe supply of quality seeds capable of sustaining the production system. The propagation of this crop is realized mainly by seeds collected from parent plants selected by the producers. Seed propagation, compared to vegetative propagation, is considered to be better for cultivation and for oil production (Duong et al., 2013). Therefore, the seed is a source both of raw material, i.e., of oil for the production of biodiesel, and of the main propagating material. However, there is not an organized system for production and commercialization of seeds of this species in Brazil yet (Silva et al., 2012), nor the procedures for the germination test are described in the official standards for seed analysis. To meet the demand for plant propagation material to establish the crops, besides standardized methods for evaluating seed quality, good storage conditions should be considered for commercialization purposes. In addition, little attention has been given to the development of seed storage methods, which is one of the major problems in tropical agriculture.

Several factors influence seed deterioration during storage, such as temperature and high relative humidity, which increase the speed of degradation of the seeds. Thus, reducing the level of these factors might increase the storage time (Castellión et al., 2010). The approach of the environmental effects on the intensity of seed deterioration can not disregard the joint action of water and temperature (Marcos-Filho, 2015). Seeds of oleaginous plants are difficult to preserve during storage since they are very prone to deterioration. In general, the intensity and speed of the deterioration process are connected to the chemical composition of the seeds. Jatropha seeds may have up to $40 \%$ oil content (Achten et al., 2007), thus requiring special attention and care during storage in order to maintain their viability and vigor (Pereira et al., 2013).

Adequate conditions during storage may delay the aging of seeds, thus increasing the preservation capacity. There is a natural reduction in germination and vigor of jatropha seeds during storage, regardless of the environmental conditions and packaging used. As said by Duong et al. (2013), the germination of jatropha seeds with moisture content from 8 to $10 \%$ was substantially reduced up from 12 to 24 months of storage. As observed by these authors, seeds stored at room temperature did not germinate after 12 months, and the temperature of $4{ }^{\circ} \mathrm{C}$ was the most suitable for storage. However, this moisture seemed to have been inadequate for storing seeds at $-23^{\circ} \mathrm{C}$. The results of this study confirmed the orthodox behavior of $J$. curcas seeds, according to the authors. Pereira et al. (2013), in the same line of research, verified that kraft paper and braided polypropylene packages can be used to store seeds of jatropha at $5{ }^{\circ} \mathrm{C}$ for 12 months, with a small reduction in the initial seed germination of $86 \%$. The same was not observed when the storage was performed under laboratory conditions.However, Wolka and Habte (2014) verified that jatropha seeds can be stored for 410 days in different environments and packages. In this work, seedling emergence test, in greenhouse, was used to evaluate the physiological quality of the seeds.

As mentioned, seeds of this species are not long-lasting, and by increasing the storage temperature, the loss in seed germination potential accelerates. According to MoncaleanoEscandon et al. (2013), this period is shorter than six months, and the loss in seeds viability occurs due to their own metabolism, which remains active even at low water contents, by consuming reserves, and reducing the levels of starch and soluble proteins. In addition, the authors reported that the presence of a high concentration of reducing sugars leads to glycosylation of proteins and lipid peroxidation. Consequently, free radicals are produced, causing damage to embryos, and subsequent deterioration of seeds.

Seeds quality during storage can not be improved. However, to guarantee a greater longevity, it is necessary that the storage conditions are adequate, but researches on this subject still lack investments, specially for a species that has not been totally domesticated yet. Therefore, the objective of this work was to evaluate the physiological quality of Jatroha curcas seeds stored in different types of packages and environments, for commercialization purposes.

\section{Material and Methods}

Seeds from the collection of Banco Ativo de Germoplasma de Jatropha kept by Embrapa Agroenergia, in Planaltina, Distrito Federal (DF) were used. The seeds were sent to the Laboratory of Seeds at Embrapa Recursos Genéticos e Biotecnologia, where they were maintained for 15 days in controlled conditions $\left(10^{\circ} \mathrm{C}\right.$ and $\left.30 \% \mathrm{RH}\right)$ until the beginning of the experiment. Seeds had initial moisture content of $7.1 \%$ and initial germination rate of $89 \%$, and they were stored in different packages: semi-permeable plastic bag (polyethylene) of high density ( $0.22 \mathrm{~mm}$ thick), multiwall paper bag and aluminized envelope (139 $\mu \mathrm{m}$ thick, made of polyester, adhesive, aluminum and polyethylene layers). The storage was carried out in different environments, with daily monitoring of relative humidity (RH) and temperature (T). The conditions were: cold and dry chamber (CDC) at $20{ }^{\circ} \mathrm{C}$ and $15 \% \mathrm{RH}$, both constant; refrigerator (R) (brand Consul, model CRA 34) at $7 \pm 3{ }^{\circ} \mathrm{C}$ and $48 \pm 8 \% \mathrm{RH}$; and laboratory 
environment (L) at $25 \pm 3{ }^{\circ} \mathrm{C}$ and $51 \pm 7 \% \mathrm{RH}$. Physiological seed quality and moisture content determination were performed after 3, 9 and 15 months of storage.

Moisture content: two subsamples of eight seeds each were placed in previously weighed, $4.5 \mathrm{~cm}$-diameter aluminum capsules with lid. The samples were kept in oven set at $105{ }^{\circ} \mathrm{C}$ for 24 hours (Brasil, 2009). After drying, they were maintained for 20 minutes in a desiccator for cooling, before new weighing. The percentage of water content was calculated based on the fresh weight, using the mean value of the subsamples.

Germination: the test was conducted with four replications of 25 seeds, which were previously immersed in hot water at $65{ }^{\circ} \mathrm{C}$ for five minutes. The treatment in hot water provides a more uniform and faster germination, and it is a method used to disinfect seeds of jatropha (Salomão et al., 2016) and other species (Sbalcheiro et al, 2014; Welter et al., 2011). After this period, seeds remained on the counter for superficial drying, and then they were placed over germitest paper roll, and moistened with distilled water at the proportion of $3.0 \mathrm{~mL} . \mathrm{g}^{-1}$ of paper. The paper rolls with the seeds remained in a germinator set at $25^{\circ} \mathrm{C}$ and 16 hours of light, and normal seedlings were evaluated seven days after the installation of the test. The results were expressed as the mean of the percentage of normal seedlings, in whole numbers, according to Brasil (2009). Seedlings with central tap root (main), four peripheral roots and $50 \%$ of the cotyledons exposed were considered normal (Salomão et al., 2016; Nunes et al., 2009). The germination test was carried out jointly with the assessment of seed vigor, by determining the percentage of root protrusion three days after sowing (Sbalcheiro et al., 2014), and recording the percentage of normal seedlings with main root longer than $4 \mathrm{~cm}$ in length, in the final count (Krzyzanowski et al., 1999).

Statistical analyses: for each of the three dependent variables $(\mathrm{Y} 1=\%$ normal seedlings, $\mathrm{Y} 2=$ normal seedlings with main root $\geq 4 \mathrm{~cm}$ in length, and $\mathrm{Y} 3=\%$ root protrusion), a completely randomized experimental design was used in a factorial scheme with three factors, each with three levels (treatments), i.e., a factorial scheme $3 \times 3 \times 3$, in which the variables and respective levels were: environment (cold and dry chamber, refrigerator or laboratory), type of packaging (aluminum, paper or plastic) and storage period (3, 9 or 15 months). The statistical software R (R Core Team, 2015) was used for analysis of the data, which were submitted to analysis of variance (ANOVA) and Tukey's multiple comparison test at 5\% significance, for contrast assessments. Assumptions of normality and homogeneity of residues were verified using Shapiro-Wilk test and Levene's test, and there was no need to transform the variables to be analyzed.

\section{Results and Discussion}

Table 1 shows the moisture content of seeds stored in different environments, packaging and storage periods. The initial value was $7.1 \%$, and during storage it ranged from $3.3 \%$ to $7.7 \%$. Regardless of the storage environment, when the packaging used was aluminum, seeds moisture content, in absolute values, remained practically unchanged and similar to the initial moisture before storage. Lower water contents were observed in seeds packed in paper bags and kept in cold and dry chamber. In this environment, the permeability of the paper packaging allowed loss of water at a higher rate, in comparison to the plastic packaging, which is semipermeable. In the laboratory and refrigerator environments, the relative air humidity varied and this influenced the water content of the seeds, which also depended on the packaging used. In the cold and dry chamber, where the temperature and relative humidity were constant, a gradual reduction in the water content of seeds in plastic package, which is semipermeable, was verified. The permeability of paper packaging is greater than that of plastic. Plastic packaging, by its turn, is more permeable than that made of aluminum, which is totally impermeable.

The storage environment did not influence seeds germination. However, a significant effect was verified in the interaction between packing and storage period $(\mathrm{P}=0.0092)$, and the results are presented in Table 2. Regardless of the storage environment, any packaging may be used to pack the seeds, as long as the storage period does not exceed 9 months. Wolka and Habte (2014) also found that seeds storage can be carried out in different environments and packaging for 410 days, with a seedling emergence percentage from 88

Table 1. Mean percentage of water content of jatropha seeds during storage in different environments and packaging types.

\begin{tabular}{lccc}
\hline \multirow{2}{*}{ Environment/Packaging } & \multicolumn{3}{c}{ Storage periods } \\
\cline { 2 - 4 } & 3 months & 9 months & 15 months \\
\hline Laboratory/Paper & 5.8 & 6.1 & 5.6 \\
Laboratory/Plastic & 6.3 & 6.3 & 5.9 \\
Laboratory/Aluminum & 7.1 & 7.4 & 7.4 \\
Cold and dry & 3.3 & 3.5 & 3.5 \\
chamber/Paper & & & \\
Cold and dry & 5.8 & 4.4 & 3.8 \\
chamber/Plastic & & & \\
Cold and dry & 7.4 & 7.4 & 7.4 \\
chamber/Aluminum & & 5.7 & 5.5 \\
Refrigerator/Paper & 6.6 & 7.2 & 7.0 \\
Refrigerator/Plastic & 7.4 & 7.5 & 7.7 \\
Refrigerator/Aluminum & 7.2 & & \\
\hline
\end{tabular}


to $94 \%$. However, Zonta et al. (2014) pointed out the need for a refrigerated environment to store seeds for more than 9 months, regardless of the packaging used. After storing for 15 months (Table 2), the percentage of normal seedlings that emerged from seeds that had been packed in plastic packaging was $86 \%, 11$ percentage points higher in seeds packaged in aluminum. For a period of 9 months, seed storage can be carried out in paper or plastic or aluminum packaging. According to Pinto Júnior et al. (2012), the physiological quality of jatropha seeds was preserved for a period of six months, only when the storage was performed in refrigerated environment and the seeds were stored in glass containers.

Seed germination, measured by the percentage of normal seedlings, was maintained during storage in plastic packaging, but the same did not occur in other packages (Table 2). In the period of 15 months, there was a reduction of 14 percentage points in germination of seeds packed in aluminum packaging, in relation to those stored for 3 months. In comparison to seeds kept in paper packaging, the reduction was of 12 percentage points. In the aluminum packaging, the performance of seed germination was the same after 3 and 9 months of storage and, for the paper packaging, there was a tendency of reducing seeds germination as the storage period increased. Duong et al. (2013) found a 34\% reduction in seed germination, after 12 months of storage, when they were packed in aluminum packaging at $4{ }^{\circ} \mathrm{C}$. The type of packaging also influenced the performance of jatropha seeds stored with $9.3 \%$ humidity, as verified by Pereira et al. (2013), but the storage environment was an important factor. According to these authors, there was a reduction in germination of the seeds stored in laboratory conditions and stowed in a permeable package. However, to maintain seed germination at $80 \%$ for more than 12 months, it was necessary to use a refrigerated environment. In the present study, the percentage of germination was $79 \%$, when seeds were stored for 15 months in permeable (paper) packaging, regardless of the storage environment (Table 2).

Table 2. Mean percentage of normal seedlings obtained in the germination test of jatropha seeds stored in different packagings and for different storage periods.

\begin{tabular}{cccc}
\hline \multicolumn{4}{c}{ Storage periods } \\
\hline Packaging & 3 months & 9 months & 15 months \\
\hline Aluminum & $89 \mathrm{Aa}$ & $91 \mathrm{Aa}$ & $76 \mathrm{Bb}$ \\
Paper & $90 \mathrm{Aa}$ & $88 \mathrm{Aab}$ & $79 \mathrm{ABb}$ \\
Plastic & $87 \mathrm{Aa}$ & $87 \mathrm{Aa}$ & $86 \mathrm{Aa}$ \\
\hline
\end{tabular}

Uppercase letters represent the comparison among packaging, considering a single storage period (column); lowercase letters represent the comparison among storage periods, considering a single packaging (line). Orthogonal contrasts were performed at the signifficance level of $5 \%$.
In a work carried out with jatropha seeds, Dias et al. (2016) observed that lower temperatures favored the germination of seeds stored at moisture content of $9.4 \%$ for 12 months. Seeds with water content above $9 \%$ may require refrigerated storage environment to maintain their quality, as observed by Pereira et al. (2013) and Dias et al. (2016).

Considering all packagings used in this study, the aluminized one provided agreater reduction in germination of the seeds stored for 15 months (Table 2). Therefore, it is possible to infer that the higher moisture content in seeds packed in impermeable packaging (Table 1) was not favorable to their conservation. Studying jatropha seeds storage, Guzman and Aquino (2009) verified a small reduction in germination when seeds were kept in impermeable packages, however, their moisture content was between 4 and 5\% w.b. The storage in impermeable package requires special care regarding temperature variation and seeds moisture (Rao et al., 2007). Thus, seeds water content during storage depended on the type of packaging used, which might reduce their physiological quality, as demonstrated in this work.

Triple interaction was verified among the factors studied, when the percentage of root protrusion (RP) of the seeds was evaluated. In Figure 1, the triple interaction can be observed, by noting that the simple interaction (Packaging $\mathrm{x}$ Period) differs in relation to the type of environment, being similar in the refrigerator and in the cold and dry chamber, but different from the interaction observed in the laboratory environment. Analyzes of variance were performed by considering the environmental factor as constant, and then evaluating packaging and storage period (Tables 3, 4 and 5). Table 5 shows the mean percentage of root protrusion of seeds, obtained from the interaction between the factors packaging and storage period, since this simple interaction was significant for the laboratory environment $(\mathrm{P}<0.0000)$.

There was no influence of the type of packaging on the performance of seeds stored for 3, 9 and 15 months in refrigerated environment, which comprises refrigerator (R) (Table 3) and cold and dry chamber (CDC) (Table 4). Reduction in vigor of jatropha seeds was verified by Pereira et al. (2013) in the first germination count test, when seeds were stored for 12 months and placed in paper or plastic packaging, regardless of the storage environment. In the laboratory environment (L) (Table 5), the plastic packaging should be used to store seeds for 15 months. Besides damaging the germination of the seeds (Table 2), the aluminum packaging provided a reduction in seed vigor, evaluated by the \%RP, during the 15 -month storage period (Table 5). Since this packaging is impermeable, it kept the water content of seeds above $7 \%$ (Table 1) for a longer period of storage, which may have impaired seeds vigor in a 
laboratory environment (Table 5), where conditions are not controlled. There was a trend of increasing in the percentage of RP of seeds up to the period of 9 months, for all storage and packaging environments used, with values above $80 \%$.Only the seeds stowed in plastic packaging and stored in L environment showed $86 \%$ of RP for a longer period, i.e., for 15 months of storage (Figure 1, Table 5). Dias et al. (2016) also did not observe differences in vigor of jatropha seeds stored for up to

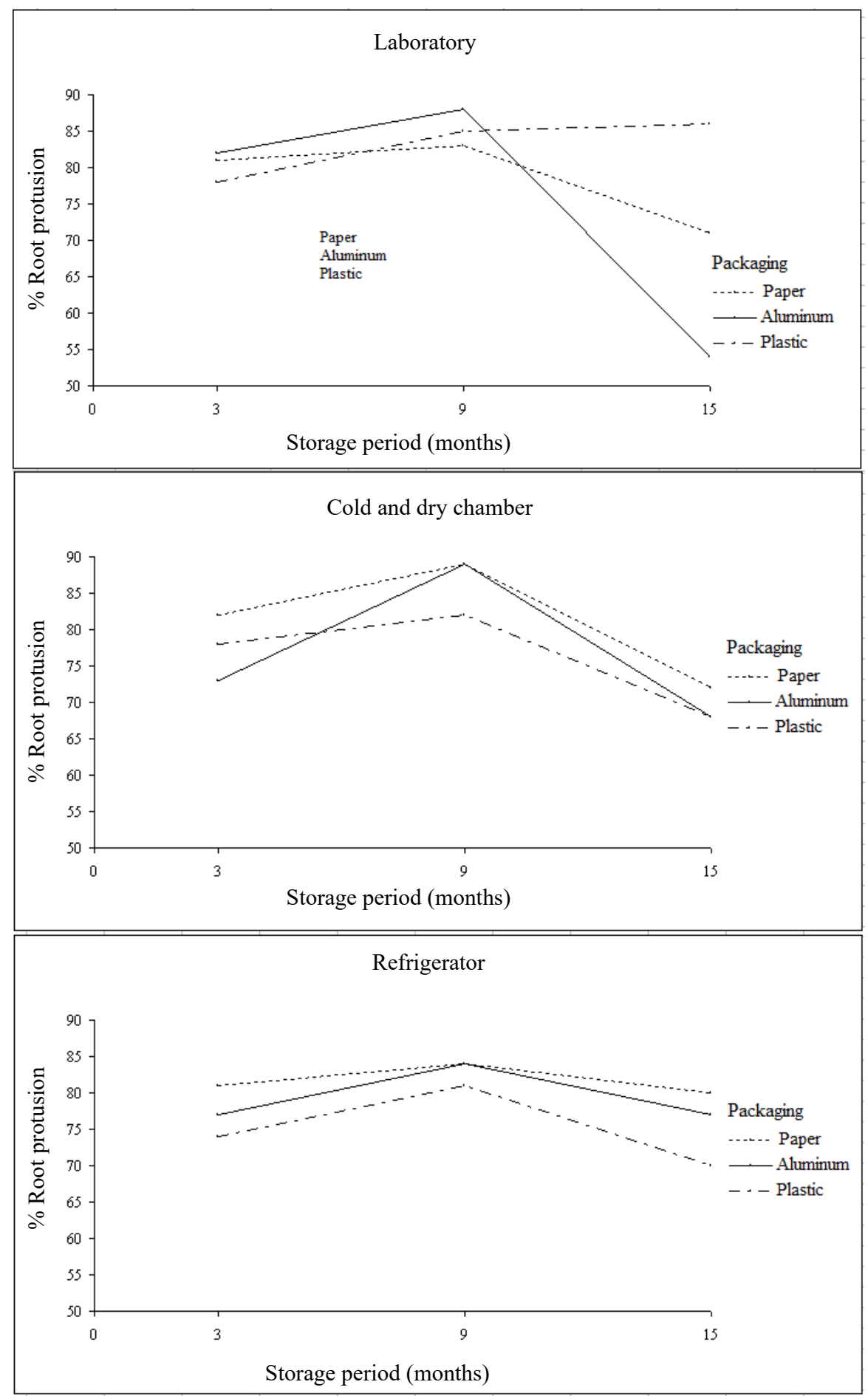

Figure 1. Percentage of root protrusion obtained in the first germination count test of jatropha seeds stored in different packagings and environments. 
9 months in environments with or without temperature control, provided they are packed in plastic or cloth bags. However, for a period of 12 months, seeds refrigeration was important for both germination and vigor. The storage period was an important factor when seeds were stored in CDC, and only $69 \%$ of RP was verified in the seeds stored for 15 months (Table 4). As mentioned by Ellis and Hong (2006), there is a critical water content for seeds, for the extension of their conservation period.

There was no significant interaction, but the environment and the storage period affected the percentage of normal seedlings with main root $\geq 4 \mathrm{~cm}$ (NSR $\geq 4 \mathrm{~cm}$ ) (Tables 6 and $7)$. The greater vigor evaluated by this test was verified in seeds stored for 9 months, and no differences were found between the 3 and 15 months periods (Table 6 ). The percentage of seeds

Table 3. Mean percentage of root protrusion obtained in the first germination count test of jatropha seeds stored in refrigerator, in different packagings and for different periods.

\begin{tabular}{ccccc}
\hline \multicolumn{5}{c}{ Storage period } \\
\hline Packaging & 3 months & 9 months & 15 months & Mean \\
\hline Aluminum & $77 \mathrm{Aa}$ & $84 \mathrm{Aa}$ & $77 \mathrm{Aa}$ & $79^{\mathrm{A}}$ \\
Paper & $81 \mathrm{Aa}$ & $84 \mathrm{Aa}$ & $80 \mathrm{Aa}$ & $82^{\mathrm{A}}$ \\
Plastic & $74 \mathrm{Aab}$ & $81 \mathrm{Aa}$ & $70 \mathrm{Ab}$ & $75^{\mathrm{A}}$ \\
\hline Mean & $77^{\mathrm{a}}$ & $83^{\mathrm{a}}$ & $76^{\mathrm{a}}$ \\
\hline
\end{tabular}

Means followed by the same lowercase letter in the line, or uppercase letter in the column, do not differ statistically by Tukey's test at $5 \%$ probability. Superscript uppercase letter represents the comparison between packages, regardless of storage period. Superscript lowercase letter represents the comparison between periods, regardless of packaging.

Table 4. Mean percentage of root protrusion obtained in the first germination count test of jatropha seeds stored in cold and dry chamber, in different packagings and for different periods.

\begin{tabular}{ccccc}
\hline \multicolumn{5}{c}{ Storage period } \\
\hline Packaging & 3 months & 9 months & 15 months & Mean \\
\hline Aluminum & $73 \mathrm{Aa}$ & $89 \mathrm{Aa}$ & $68 \mathrm{Aa}$ & $77^{\mathrm{A}}$ \\
Paper & $82 \mathrm{Aa}$ & $89 \mathrm{Aa}$ & $72 \mathrm{Aa}$ & $81^{\mathrm{A}}$ \\
Plastic & $78 \mathrm{Aab}$ & $82 \mathrm{Aa}$ & $68 \mathrm{Ab}$ & $76^{\mathrm{A}}$ \\
\hline Mean & $78^{\mathrm{b}}$ & $87^{\mathrm{a}}$ & $69^{\mathrm{b}}$ & \\
\hline
\end{tabular}

Means followed by the same lowercase letter in the line, or uppercase letter in the column, do not differ statistically by Tukey's test at $5 \%$ probability. Superscript uppercase letter represents the comparison between packages, regardless of storage period. Superscript lowercase letter represents the comparison between periods, regardless of packaging. that originated NSR $\geq 4$ augmented from the third to the ninth month of storage, and then reduced again on the fifteenth. The period of 9 months favored seeds vigor assessed both by the percentage of root protusion (Tables 3, 4 and 5), and by the development of the seedlings (Table 6). It is important noticing that the seeds came from a Germplasm Bank, and that genetic enhancement works are still in progress, so there are no commercial varieties of jatropha, yet. Thus, variations on the uniformity of fruits and seeds maturation may occur, which might have been overcome during the 9 months of storage, favoring the performance of the seeds in the vigor tests performed. The mean of the percentage of NSR $\geq 4 \mathrm{~cm}$ from seeds stored in the environment $\mathrm{R}$ increased in $12 \%$, in comparison to the environment L (Table 7). Similar results were

Table 5. Mean percentage of root protrusion obtained in the first germination count test of jatropha seeds stored in laboratory environment, in different packagings and for different periods.

\begin{tabular}{cccc}
\hline & \multicolumn{3}{c}{ Storage period } \\
\hline Packaging & 3 months & 9 months & 15 months \\
\hline Aluminum & $82 \mathrm{Aa}$ & $88 \mathrm{Aa}$ & $54 \mathrm{Cb}$ \\
Paper & $81 \mathrm{Aab}$ & $83 \mathrm{Aa}$ & $71 \mathrm{Bb}$ \\
Plastic & $78 \mathrm{Aa}$ & $85 \mathrm{Aa}$ & $86 \mathrm{Aa}$ \\
\hline
\end{tabular}

Means followed by the same lowercase letter in the line, or uppercase letter in the column, do not differ statistically by Tukey's test at $5 \%$ probability.

Table 6. Mean percentage of normal seedlings with main root $\geq 4 \mathrm{~cm}$ (NSR $\geq 4 \mathrm{~cm}$ ) obtained in the final count of the germination test of jatropha seeds stored for different periods.

\begin{tabular}{cc}
\hline Storage period & NSR $\geq 4 \mathrm{~cm}$ \\
\hline 3 months & $59 \mathrm{~B}$ \\
9 months & $76 \mathrm{~A}$ \\
15 months & $65 \mathrm{~B}$ \\
\hline
\end{tabular}

Means followed by the same uppercase letter in the column do not differ statistically by Tukey's test at $5 \%$ probability.

Table 7. Mean percentage of normal seedlings with main root $\geq 4 \mathrm{~cm}$ (NSR $\geq 4 \mathrm{~cm}$ ) obtained in the final count of the germination test of jatropha seeds stored in different environments.

\begin{tabular}{cc}
\hline Storage period & NSR $\geq 4 \mathrm{~cm}$ \\
\hline Cold and dry chamber (CDC) & $67 \mathrm{AB}$ \\
Refrigerator (R) & $71 \mathrm{~A}$ \\
Laboratory (L) & $63 \mathrm{~B}$ \\
\hline
\end{tabular}

Means followed by the same uppercase letter in the column do not differ statistically by Tukey's test at $5 \%$ probability. 
obtained by Pereira et al. (2013) and Duong et al. (2013), who observed that the conservation of jatropha seeds in refrigerated environment favored their vigor. A comparison between the storage environments $\mathrm{CDC}$ and $\mathrm{R}$ showed a reduction trend in root development (NSR $\geq 4 \mathrm{~cm}$ ), when seeds were submitted to cold and dry storage (CDC). This suggests that the low water content of seeds, caused by storing them in a cold and dry place, did not favored seedling development, which influenced the \%RP. As mentioned by Torres et al. (1997), a decrease in vigor and viability of seeds during aging may be associated with the activity of antioxidant enzymes and, therefore, with the increase of lipid peroxidation, mainly in oilseeds. Peroxide formation in the cells during storage may also be related with seeds moisture content, as observed by José et al. (2010) in sunflower seeds. In addition, the methabolism of jatropha seeds remains active, even in low water contents, consuming their reserves during storage, and this can affect the seeds quality, according to studies performed by MoncaleanoEscandon et al. (2013).

\section{Conclusions}

Jatropha seeds can be stored for up to 15 months without loosing viability, provided they arestowed in semipermeable plastic packaging.

The vigor of jatropha seeds is maintained for a period of 9 months for the different storage environment and packaging used in this study.

\section{References}

ABDELGADIR, H. A.; JOHNSON, S. D.; VAN STADEN, J. Approaches to improve seed production of Jatropha curcas L. South African Journal of Botany, v. 74, p. 359, 2008. http://www. scielo.br/scielo.php?script $=$ sci_nlinks\&ref $=000058 \&$ pid $=$ S0101$3122201200040000500001 \& \operatorname{lng}=$ en

ACHTEN, W. M. J.; MATHIJS, E.; VERCHOT, L.; SINGH, V. P.; AERTS, R.; MUYS, B. Jatropha biodiesel fueling sustainability? Biofuels Bioproducts and Biorefining, v.1, p. 283-291, 2007. http:// onlinelibrary.wiley.com/doi/10.1002/bbb.39/epdf

BRASIL. Ministério da Agricultura, Pecuária e Abastecimento. Regras para análise de sementes. Ministério da Agricultura, Pecuária e Abastecimento. Secretaria de Defesa Agropecuária. Brasília: MAPA/ACS, 2009. 395p. http://www.agricultura.gov.br/arq_editor/ file/2946_regras_analise_sementes.pdf

CASTELLIÓN, M.; MATIACEVICH, S.;BUERA,P.; MALDONADO, $\mathrm{S}$. Protein deterioration and longevity of quinoa seeds during long-term storage. Food Chemistry, v.121, n.4, p.952-958, 2010. http://www. sciencedirect.com/science/article/pii/S0308814610001056
DIAS, D.C.F.S.; OLIVEIRA, G.L.; VALLORY, G.G.; SILVA, L.J.; SOARES, M.M. Alterações fisiológicas em sementes de Jatropha curcas L. durante o armazenamento. Jounal of Seed Science, v. 38, n.1, p.41-49, 2016.http://www.scielo.br/scielo.php?script=sci_ arttext\&pid=S2317-15372016000100041

DUONG, T. H.; SHEN, J. L.; LUANGVIRIYASAENG, V.; HA, H. T.; PINYOPUSARERK, K Storage behaviour of Jatropha curcas seeds. Journal of Tropical Forest Science, v.25, n.2, p. 193-199, 2013. http://www.frim.gov.my/v1/JTFSOnline/jtfs/v25n2/193-199.pdf

ELLIS, R.H.; HONG, T.D. Temperature sensitivity of the low-moisture content limit to negative seed longevity moisture content relationships in hermetic storage. Annals of Botany, v.97, n.5, p.785-791, 2006. https:// www.ncbi.nlm.nih.gov/pmc/articles/PMC2803418/

FREITAS, R. G.; MISSIO, R. F.; MATOS, F. S.; RESENDE, M. D. V.; DIAS, L. A. S. Genetic evaluation of Jatropha curcas: an important oil seed for biodiesel production. Genetics and Molecular Research, v.10, n.3, p.1490-1498, 2011. http://dx.doi.org/10.4238/ vol10-3gmr1146

GUZMAN, L.E.P.; AQUINO, A. L. Seed characteristics and storage behavior of physic nut (Jatropha curcas L.). Philippine Journal of Crop Science (PJCS), v.34, n.1, p.13-21, 2009. https://www. researchgate.net/publication/281863148_Seed_Characteristics_ and_Storage_Behavior_of_Physic_Nut_Jatropha_curcas_L

JOSÉ, S.C.B.R.; SALOMÃO, A.N.; COSTA, T.S.A.; SILVA, J. T.T.T.; CURI, C.C.S. Armazenamento de sementes de girassol em temperaturas subzero: aspectos fisiológicos e bioquímicos. Revista Brasileira de Sementes, v.32, n.4, p.29-38, 2010. http://www.scielo. br/scielo.php?script=sci_arttext\&pid=S0101-31222010000400004

KRZYZANOWSKI, F. C.; VIEIRA, R. D.; FRANÇA-NETO, J.B. (Ed.). Vigor de sementes: conceitos e testes. Londrina: ABRATES, 1999. $218 \mathrm{p}$.

LAVIOLA, B. G.; BHERING, L. L.; MENDONÇA, S.; ROSADO, T. B.; ALBRECHT, J. C. Caracterização morfo-agronômica do banco de germoplasma de pinhão-manso na fase jovem. Bioscience Journal, v.27, n.3, p.371-379, 2011. http://www.seer.ufu.br/index. $\mathrm{php} /$ biosciencejournal/article/view/7651/7552.

MARCOS-FILHO, J. Fisiologia de sementes de Plantas Cultivadas.2.ed. Londrina: ABRATES, 2015. 660p.

MONCALEANO-ESCANDON, J.; SILVA, B. C. F.; SILVA, S.R. S.; GRANJA, J. A.A.; ALVES, M. C. J. L.; POMPELLI, M. F. Germination responses of Jatropha curcas L. seeds storage and aging. Industrial Crops and Products, v.44, p.684-690, 2013. https:// www.ufpe.br/lev/images/pdf/pdfsmarcelo/marcelo_19.pdf

NUNES, C.F.; SANTOS, D.N.; PASQUAL, M.; VALENTE, T. C. T. Morfologia externa de frutos, sementes e plântulas de pinhãomanso. Pesquisa Agropecuária Brasileira, Brasília, v.44, n.2, p.207-210, 2009. http://ainfo.cnptia.embrapa.br/digital/bitstream/ item/106118/1/Morfologia-externa.pdf

PINTO JUNIOR, A.S.; GUIMARÃES, V.F.; DRANSKI, J.A.L.; STEINER, F.; MALAVASI, M.M.; MALAVASI, U.C. Armazenamento de sementes de pinhão manso em diferentes embalagens e ambientes. Revista Brasileira de Sementes, v.34, n.4, p.636 -643, 2012.http://www.scielo.br/pdf/rbs/v34n4/15.pdf 
PEREIRA, M.D.; DIAS, D.C.F.S.; BORGES, E.E.L.; MARTINS FILHO, S.; DIAS, L.A.S.; SORIANO, P.E. Physiological quality of physicnut (Jatropha curcas L.) seeds during storage. Journal of Seed Science, v.35, n.1, p.21-27, 2013. http://www.scielo.br/pdf/jss/ v35n1/03.pdf

RAO, N. K.; HANSON, J.; DULlOO, M. E.; GHOSH, K.; LARINDE, M. Manual para el manejo de semillas en bancos de germoplasma. Roma: BioversityInternational, 2007. 165 p. (Manuales para Bancos de Germoplasma, 8).

$\mathrm{R}$ - DEVELOPMENT CORE TEAM. A language and environment for statistical computing. Vienna: R Foundation for Statistical Computing, 2015. http://www.R-project.org/

SALOMÃO, A.N.; SANTOS, I.R.I.; JOSÉ, S.C.B.R.; SILVA, J.P.; LAVIOLA, B.G. Methods to assess the viability of cryopreserved Jatropha curcas L. seed germplasm. Revista Brasileira de Plantas Medicinais, v.18, n.2, p.391-398, 2016. http://www.scielo.br/pdf/ rbpm/v18n2/1516-0572-rbpm-18-2-0391.pdf

SBALCHEIRO, C. C.; JOSE, S. C. B. R.; BARBOSA, J. C. R. C. M. Physiological and sanitary quality, and transmission of fungi associated with Brachiaria brizantha (Hochst. ex. A. Rich.) Stapf seeds submitted to thermal and chemical treatments. Journal of Seed Science, v. 36, n. 4, p. 443-450, 2014. http://dx.doi.org/10.1590/2317$1545 \mathrm{v} 36 \mathrm{n} 41032$

SILVA, L.J.; DIAS, D.C.F.S.; MILAGRES, C.C.; DIAS, L.A.S. Relationship between fruit maturation stage and physiological quality of physic nut (Jatropha curcas L.) seeds. Revista Ciência e Agrotecnologia, v. 36, n. 1, p. 39-44, 2012. http://www.scielo.br/ scielo.php?pid=S1413-70542012000100005\&script $=$ sci_arttext
TORRES, M.; PAULA, M.; PÈREZ_OTAOLA, M.; DARDER, M.; FRUTOS, G.; MARTINEZ_HONDUVILLA, C. Ageinginduced changes in glutathione system of sunflower seeds. Plant Physiology, v.133, n.2, p.600-604, 1997.http://onlinelibrary.wiley. com/doi/10.1111/j.1399-3054.1997.tb01067.x/epdf

WELTER, M. K.; SMIDERLE, O.J.; UCHÔA, S.C.P.; CHANG, M.T.; MENDES, E.P. Germinação de sementes de maracujá amarelo azedo em função de tratamentos térmicos. Revista Agro @)mbiente On-line, v.5, n.3, p.227-232, 2011. http://revista.ufrr.br/ agroambiente/article/viewFile/626/618

WOLKA, K.; HABTE, Y. Effect of seed storage period and condition on viability of Jatropha curcasL. seed. Research Journal of Forestry, v.8, n.2, p.56-63, 2014.http://scialert.net/qredirect. php?doi=rjf.2014.56.63\&linkid=pdf

ZONTA, J.B.; ARAUJO, E.F.; ARAUJO, R.F.; ZONTA, J.H.; DIAS, L.A.S.; RIBEIRO, P.H. Armazenamento de sementes de pinhão manso em diferentes embalagens e ambientes. Bioscience Journal, v. 30, n.5, supplement 2, p. 599-608, 2014. http://www.seer.ufu.br/ index.php/biosciencejournal/article/view/18207/15220 